\title{
Impact of Diversification of Cultivable Area on Production of Sugarcane in Kabirdham
}

\author{
Birbal Nag*, Gayatri Chandrakar and Chowa Ram Sahu \\ Dept. of Agricultural Statistics \& Social Science (L.), IGKV, Raipur, (C.G.), India \\ *Corresponding author
}

\section{A B S T R A C T}

\begin{tabular}{l} 
Ke y w o r d s \\
$\begin{array}{l}\text { Production } \\
\text { of Sugarcane, } \\
\text { Saccharum } \\
\text { officinarum }\end{array}$ \\
\hline Article Info \\
$\begin{array}{l}\text { Accepted: } \\
\text { 07 November } 2020 \\
\text { Available Online: } \\
\text { 10 December } 2020\end{array}$ \\
\hline
\end{tabular}

10 December 2020
Sugarcane (Saccharum officinarum L.) is an important commercial crop in India and plays an important role in industrial and agricultural economy of our country. Chhattisgarh, the state which has been known as Bowl of Rice of the country. The sugar production in all four factories (two in Kabirdham, one in Balod and one in Surajpur district) in the state had reached 65000 metric tons. The major crops grown in the study area Paddy, Sugarcane, Wheat, Gram, Soybean, Vegetables and Pigeon pea in Kabirdham district. A stratified random sampling has been conducted for estimation of study variable under proportional allocation among the strata and statistical technique Herfindahl Index has been used for computation of crop diversification index in different blocks of Kabirdham district. Paddy covered highest cropped area in Kawardha, Bodla and Pandariya blocks are $38.90 \%, 42.45 \%$ and $46.11 \%$ respectively. Sugarcane covered highest cropped area in Kawardha, Bodla and Pandariya blocks are $33.16 \%, 36.95 \%$ and $38.40 \%$ respectively. The estimated area under Sugarcane in Kawardha, bodla and Pandariya are 8823.6 ha, 6698.16 ha and 8633.58 ha respectively and overall for Kabirdham district it is 24155.34 ha. The estimated production under Sugarcane in Kawardha, Bodla and Pandariya are 2218593.6 quintal, 1667593.76 quintal and 2078359.38 quintal respectively and overall for Kabirdham district it is 5964546.74 quintal. The crop diversification index moved in a narrow range during the post change period in almost all the blocks in Kabirdham district. The acreage crop diversification index of the district increased from 0.64 to 0.67 , which shows diversified to more remunerative crops. The constraints pertaining to cultivation of Sugarcane, lack of institutional support was the major problem as reported by $(83.80 \%)$ Sugarcane growers.

\section{Introduction}

Sugar is one of the oldest commodities in the world and traces its origin in $4^{\text {th }}$ century $\mathrm{AD}$ in India and China. India has known as the original home of sugarcane and sugar. India is the second largest producer of sugar in the world after Brazil and produces mainly sugarcane. It produces around 22 million tons of sugar annually. The growth of sugarcane agriculture in the country had been consistent during the past seven decades. There was increase in area, production and productivity and sugar recovery during the period 1930-31 to 2017-18, the area under sugarcane had gone up from 1.18 million ha to 5.14 million 
ha, productivity from 31 tons to 62.8tons per hectare and total cane produces from 37 million tons to 340 million tons.

Sugar industry is the second largest agrobased processing industry after cotton textiles industry in the country. India is the largest consumer and second largest producer of sugar in world. In 2016-17, India produces 21.3 million tons and consumed 18.5 million tons of sugar, the lowest in seven year. In 2015-16, the mills produced 25.1 million tons. India is the largest consumer of sugar, accounting for 15 per cent of global consumption.

India is the only country in which sugarcane grown in both types of the climate i.e. tropical and subtropical. Sugarcane (Saccharum officinarum L.) is an important commercial crop in India and plays an important role in industrial and agricultural economy of our country. Sugarcane in agriculture sector shares 7 percent of the total value of agricultural output and occupies only 2.5 per cent of India gross cropped area. Apart from this, sugarcane is in great demand for various other uses like fodder, paper production and most importantly biofuels. Sugarcane produces sugar, jaggery, khandsari, molasses from which ethanol is produced press mud which is used as a plant nutrients source, bagasse used for cogeneration of power to produce electricity and for manufacturing paper. The important sugarcane growing states in the country are Uttar Pradesh, Maharashtra, Tamil Nadu, Karnataka, Andhra Pradesh, Madhya Pradesh, Bihar etc. Among the states, Uttar Pradesh leads in area 2.23 million hectares and production 135.16 million tons and West Bengal leads in per ha productivity 100.29 tons/ha.

Chhattisgarh, the state which has been known as Bowl of Rice of the country. The sugar production in all four factories (two in
Kabirdham, one in Balod and one in Surajpur district) in the state had reached 65000 metric tons. Chhattisgarh has three sugar mills and new co-operative sugar factory with sugarcane crushing capacity of 2,500 metric tons will come up in Chhattisgarh's Kabirdham district, with a vision to promote agro-based industries in the state. In spite of this, sugar prices in Chhattisgarh are always varying.

Former Chief Minister of Chhattisgarh Dr. Raman Singh laid the foundation stone of the factory, to be constructed at Biseshar village of Pandariya block at a cost of Rs.163.12crore. The factory premises would be spread in an area measuring over 80 hectares. "Over 10,000 farmers in the region are stock-holders in this factory and thus they are its real owners," he said. Notably, this is the fourth sugar factory of the state and second in Kabirdham district, based on cooperative model. This factory, which has been name after India's 'Iron man' Sardar Vallabbhai Patel, will benefit about 20,000 farmers living in Pandariya region of Kabirdham, besides Mungeli and Bemetara districts.

Sugarcane production has changed the standard of living of farmers, residing in Pandariya block. It has not only resulted in growth of income but also led to development of farmers. Sugarcane farming is more beneficial for farmers than farming other crops. Kisan Credit Card and Sugar Industry have led to increase in Sugarcane farming in Kabirdham during the past 8 years.

The state government requires 57500 metric tons of sugar per annum for distribution to the ration cardholders through the public distribution system. The scope of sugarcane cultivation is bright in the Kabirdham district and production was 26315 metric tons in 2016-17. 


\section{Study area}

The study conducted in Kawardha, Bodla, Sahaspur Lohara and Pandariya blocks of Kabirdham district of Chhattisgarh state during the year 2017-18. Kabirdham district is located at a distance of $128 \mathrm{~km}$ away from Raipur. Kabirdham district is located in C.G. Plains of Chhattisgarh state.

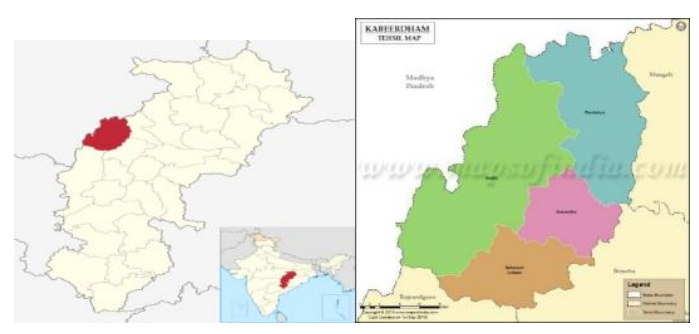

\section{Materials and Methods}

The study were collected by survey method using questionnaire prepared specially for the purpose (appendix) were collected from Bhoramdeo and Louh Purush Sardar Vallabhbhai Patel S.S.U.K.M. Kabirdham district of Chhattisgarh state during 2017-18.

\section{Description of the model}

Sugarcane growing area in Kabirdham district of Chhattisgarh has been taken as the target population whose sampled population comprises of four strata mainly Kawardha, Bodla, Sahaspur Lohara, and Pandariya blocks.

A stratified random sampling has been conducted for estimation of study variable under proportional allocation among the strata.

\section{Determination of sample size}

In preparation of a sample, investigation is about the size of the sample required for estimating the population parameter with specified accuracy. The accuracy is usually specify in term of the margin of error acceptable in the estimate and the coefficient of confidence with which one wants to make sure that the estimate is within the permissible margin of error. Thus if the error permissible in the estimate of the population value of the mean is say $\varepsilon \stackrel{y}{N}$ so that

Sample size, $\mathrm{n}={\frac{z^{2} s^{2}}{\varepsilon^{2} Y_{N}}}^{2}$

Where,

$S^{2}=$ Population variance, $\varepsilon=10 \%$ margin of error, $\underline{Y}_{N}=$ Population mean,

$\mathrm{Z}=$ Confidence coefficient at $95 \%$

\section{Computation of population total and its variance}

Let $i$ denoted for the stratum and $j$ for the sampling unit within the stratum. The following notation refers to stratum $i$ :

$N_{i}=$ total no. of unit

$n_{i}=$ no. of unit in sample

Let $y_{i j}$ be the value of the $j^{\text {th }}$ unit in the stratum

$\underline{Y}_{i}=\sum_{j}^{N i} \quad y_{i j} / N i$ stratum mean

$\underline{y}_{i}=\sum_{j}^{n i} \quad y_{i j} / n_{i}$ sample mean

$S_{i}^{2}=\sum_{j}^{N i} \quad\left(y_{i j}-\underline{Y}_{i}\right)^{2} /\left(N_{i}-1\right) \quad$ stratum variance

Assume that a population of $\mathrm{N}$ units is divided into $\mathrm{k}$ strata. The population mean per unit can be written as,

$\underline{Y}=\frac{\sum_{i}^{k} \sum_{j}^{N i} Y_{i j}}{N}$ 
$=\sum_{i}^{k} \quad N_{i} \underline{Y}_{i} / N$

An estimator $\underline{y}_{s t}(s t$ for stratified) for the population mean $\underline{Y}$ can be written as

$\underline{y_{s t}}=\sum_{i}^{k} \quad N_{i} y_{i} / N$

and its variance

$V\left(\underline{y}_{s t}\right)=\sum_{i}^{k} \quad N_{i}\left(N_{i-} n_{i}\right) S_{i}^{2} / N^{2} n_{i}$

And standard error SE $\underline{\left(y_{s t}\right)}=\sqrt{V\left(y_{s t}\right)}$

As we know $\hat{Y}_{s t}=N \cdot .^{s t}$, then sampling variance is given by

$V \quad\left(\hat{Y}_{s t}\right)=V \quad\left(N \cdot \underline{y}^{s t}\right)=N^{2} \cdot V\left(\underline{y}_{s t}\right)$

$=\sum_{i}^{k} \quad N_{i}\left(N_{i-} n_{i}\right) S_{i}^{2} / n_{i}$

And $S E\left(\hat{y}_{s t}\right)=\sqrt{V\left(\hat{Y}_{s t}\right)}$

\section{$\mathrm{Z}$ test statistic}

For test of Significance for difference between two means with unequal $\nabla_{1}$ and $\nabla_{2}$ values, the statistic $\mathrm{Z}$ can be computed as,

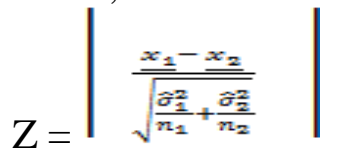

Where,

$\underline{x}_{1}-\underline{x}_{2}=$ difference between two sample means $\underline{x}_{1}$ and $\underline{x}_{2}$

$\hat{\theta}_{1} \& \hat{0}_{2}$ are the estimated standard deviations of population 1 and population 2 .

$n_{1} \& n_{2}=$ number of sizes in large sample 1 and sample 2 .

\section{Measurement of crop diversification}

Statistical technique Herfindahl Index has been accepted from Malik (2002). It is computed by taking the sum of square of acreage proportion of each crop to the total cropped area. Mathematically, the index is as follows:

$H_{D}=\sum_{j=1}^{n} \quad\left\{\frac{x_{j}}{\sum_{j=1}^{n}} Y_{j}\right\}^{2} \quad 0 \leq H_{D \leq 1}$

Where,

$Y_{j}$ is represented the area share occupied by the $i^{\text {th }}$ crop in total area Y.

$\mathrm{n}$ is the number of crops

Herfindahl index defined as the sum of squares of all $\mathrm{j}$ proportions is a measure of crop concentration. This measure is used to measure of crop diversification on acreage proportion. The value of H.I. varies from zero to one. It takes the value of one when there is complete specialization and approaches zero when the number enterprises is more showing perfect diversification.

\section{Results and Discussion}

Area under sugarcane in Kabirdham district of Chhattisgarh: For estimation of area of Sugarcane, stratified random sampling were use. There are four strata as Kawardha, Bodla, Sahaspur Loharaand Pandariya block. Sugarcane grower farmers in Kawardha, Bodla, Sahaspur Loharaand Pandariya block were $7740,6202,40$, and 7778 respectively. Out of which samples were taken as 75, 60, 1 and 75 respectively (Fig. 1).

In Table 1, Column number (f) shows the estimated area under Sugarcane in different blocks like Kawardha, Bodla, and Pandariya respectively. So estimated area under Sugarcane in Kawardha, bodla and Pandariya 
are 8823.6 ha, 6698.16 ha and 8633.58 ha respectively and overall for Kabirdham district it is 24155.34 ha. Thus, we can say that total area covered in Kabirdham district under Sugarcane is 24155.34 ha with standard error 981.28 ha.

On the record of Bhoramdeo and Louh Purush Sardar Vallabhbhai Patel S.S.U.K.M. Kabirdham district of Chhattisgarh, area under Sugarcane grown in the study area are 5038.816 ha in Kawardha, 3867.836 ha in Bodla and 8013.1672 ha in Pandariya. The overall 16919.8192 ha for Kabirdham district.

Production under sugarcane in Kabirdham district of Chhattisgarh: For estimation of production of Sugarcane, stratified random sampling were use. There are three strata Kawardha, Bodla and Pandariya blocks.

Table.1 Estimation of area under Sugarcane

\begin{tabular}{|c|c|c|c|c|c|c|c|}
\hline $\begin{array}{l}\text { Strata as a } \\
\text { blocks }\end{array}$ & $\begin{array}{l}\text { Total } \\
\text { farmers }\end{array}$ & $\begin{array}{l}\text { Sampled } \\
\text { farmers } m_{n_{k}}\end{array}$ & $\begin{array}{c}\text { Mean } \\
\underline{W_{i}}\end{array}$ & $\underset{\substack{a^{2} \\
z_{i}}}{\text { Variance }}$ & $\mathbb{B S W}_{2}$ & $\left(\frac{1}{m_{1}}-\frac{1}{B_{i}}\right)$ & 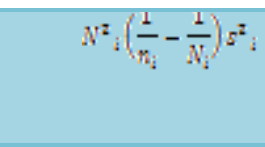 \\
\hline (a) & (b) & (c) & (d) & (e) & (f) & (g) & (h) \\
\hline Kawardha & 7740 & 75 & 1.15 & 0.3084 & 8823.6 & 0.0132 & 243876.651 \\
\hline Bodla & 6202 & 60 & 1.08 & 0.5513 & 6698.16 & 0.0165 & 349893.166 \\
\hline Pandariya & 7778 & 75 & 1.11 & 0.4588 & 8633.58 & 0.0133 & 369156.847 \\
\hline Total & 21720 & 210 & & & 24155.34 & & 962926.664 \\
\hline
\end{tabular}

Table.2 Estimation of production under Sugarcane

\begin{tabular}{|c|c|c|c|c|c|c|c|}
\hline $\begin{array}{l}\text { Strata as a } \\
\text { blocks }\end{array}$ & $\begin{array}{l}\text { Total } \\
\text { farmers } \\
S_{1}\end{array}$ & $\begin{array}{l}\text { Sampled } \\
\text { farmers }\end{array}$ & $\underset{\substack{\underline{D}_{i} \\
\text { Mean }}}{ }$ & $\begin{array}{c}\text { Variance } \\
a^{z_{i}}\end{array}$ & $\mathbb{B S}_{Y_{2}}$ & $\left\{\frac{1}{m_{1}}-\frac{1}{B_{2}}\right]$ & 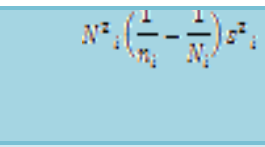 \\
\hline (a) & (b) & (c) & (d) & (e) & (f) & (g) & (h) \\
\hline Kawardha & 7740 & 75 & 286.54 & 20091.69 & 2218593.6 & 0.0132 & 15888113048 \\
\hline Bodla & 6202 & 60 & 268.88 & 34957.04 & 1667593.76 & 0.0165 & 22186158918 \\
\hline Pandariya & 7778 & 75 & 267.21 & 30803.56 & 2078359.38 & 0.0133 & 24784971843 \\
\hline Total & 21720 & 210 & & & 5964546.74 & & 62859243809 \\
\hline
\end{tabular}

Table.3 Block wise calculation of crop diversification index

\begin{tabular}{|c|c|c|c|c|c|}
\hline \multirow[t]{2}{*}{ S.N. } & \multirow[t]{2}{*}{ Strata/blocks } & \multirow[t]{2}{*}{$\begin{array}{l}\text { Range of } \\
\text { category }\end{array}$} & \multirow[t]{2}{*}{ category } & \multicolumn{2}{|c|}{$\begin{array}{l}\text { Crop Diversification } \\
\text { Index }\end{array}$} \\
\hline & & & & $2012-13$ & 2017-18 \\
\hline (a) & (b) & (c) & (d) & (e) & (f) \\
\hline 1. & Kawardha & Above 0.65 & High & 0.692 & 0.721 \\
\hline 2. & Bodla & $0.55-0.65$ & Medium & 0.636 & 0.670 \\
\hline 3. & Pandariya & $0.45-0.55$ & Low & 0.615 & 0.632 \\
\hline \multirow[t]{2}{*}{4.} & $\begin{array}{l}\text { Sahaspur } \\
\text { Lohara }\end{array}$ & Below 0.45 & Very low & 0.608 & 0.618 \\
\hline & $\begin{array}{l}\text { Kabirdham } \\
\text { district }\end{array}$ & & & 0.64 & 0.67 \\
\hline
\end{tabular}


Fig.1 Comparison between estimated area and official data under Sugarcane in different blocks of Kabirdham district

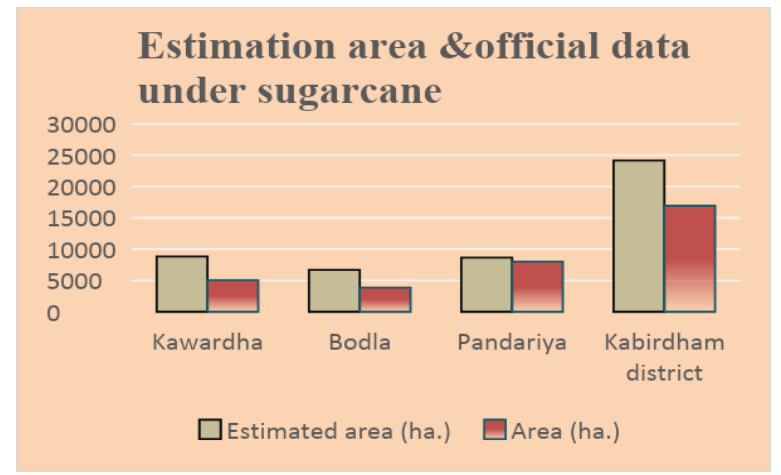

In Table 2 column number (f) shows the estimated production under Sugarcane in different blocks like Kawardha, Bodla and Pandariya. So estimated production under Sugarcane in Kawardha, Bodla and Pandariya are 2218593.6 quintal, 1667593.76 quintal and 2078359.38 quintal respectively \& overall for Kabirdham district it is 5964546.74 quintal. Thus, we can say that total production in Kabirdham district under Sugarcane is 5964546.74 quintal with S.E. 250717.5 quintal.

\section{Crop diversification index}

Crop diversification means a shift from traditionally grown less remunerative crops to more remunerative crops. It depends on geoclimatic, socio-economic conditions and technological development in a region. Crop diversification designed to a shift from the regional dominance of one crop to regional production of a number of crops and to meet ever increasing demand of coarse cereals, pulses, vegetables, fruits, oilseeds and sugarcane. Crop diversification is intended to promote technological innovations for sustainable agriculture and enable farmers to choose crop alternatives for increased productivity and income.

Statistical technique Herfindahl index has been used for computation of crop diversification index in different blocks of Kabirdham district and presented in Table 3.

In Table 1.3, Crop diversification were classified under different categories as high, medium, low and very low as per Beejata Das (2012), and presented in column number (c) and (d). Crop diversification index were given in column number (e) and (f) for year 201213 and 2017-18 respectively.

During 2012-13 to 2017-18, the crop diversification index on acreage proportions in different block of Kabirdham district has been presented in the above Table. The value of crop diversification index moved in a narrow range during the post change period in almost all the four blocks. The average crop diversification index value of the district increased from 0.64 to 0.67 , which shows diversified to more remunerative crops.

\section{Constraints in production of Sugarcane}

The constraints faced by Sugarcane growers. Under major constraints pertaining to cultivation of sugarcane, lack of institutional support was the major problem as reported by $(83.80 \%)$ sugarcane growers. The second most important constraints faced by the growers were lack of market news and intelligence $(74.76 \%)$. The other important constraints reported by the growers were 
shortage of labour (71.90\%), lack of knowledge about new technology, improved, high yielding variety and package practices of crops $(63.33 \%)$.

From the derived results, it was found that crop diversification index moved in a narrow range during the post reform period in almost all the Kabirdham district. The acreage crop diversification index of the district increased from 0.64 to 0.67 , which shows diversified to more remunerative crops.

In the four blocks crop diversification index has increased from 0.692 to 0.721 in Kawardha, 0.636 to 0.670 in Bodla, 0.615 to 0.632 in Pandariya and 0.608 to 0.618 in Sahaspur Lohara respectively.

The Kawardha and Bodla blocks came under the high crop diversification and the two remaining blocks came under the medium crop diversification during 2017-18.

\section{References}

Das, Beejata, 2012. Pattern of crop diversification and disparities in Agriculture, Centre for Studies in Geography, Dibrugarh University, India: 37-40.

Jha, Brajesh, 2009. Pattern of Agricultural Diversification in India: 2-12.

Malik, D.P. and Singh, I.J. 2002. Crop diversification - An economics analysis, CCS Haryana Agricultural University Hisar, India: 61-64.

Shukla, S.K. and Singh, K.K. 2016. Crop diversification options involving Pulse and Sugarcane for improving crop productivity, Nutritional security and sustainability in India: 1-10.

\section{How to cite this article:}

Birbal Nag, Gayatri Chandrakar and Chowa Ram Sahu. 2020. Impact of Diversification of Cultivable Area on Production of Sugarcane in Kabirdham. Int.J.Curr.Microbiol.App.Sci. 9(12): 665-671. doi: https://doi.org/10.20546/ijcmas.2020.912.080 